\title{
Metabolomic analysis of uterine serous carcinoma with acquired
} resistance to paclitaxel

This article has been corrected. Correction in Oncotarget. 2021; 12:2321-2322.

Manabu Seino', Tsuyoshi Ohta ${ }^{1}$, Akiko Sugiyama ${ }^{1}$, Hirotsugu Sakaki ${ }^{1}$, Takeshi Sudo ${ }^{1}$, Seiji Tsutsumi ${ }^{1}$, Shogo Shigeta ${ }^{2}$, Hideki Tokunaga ${ }^{2}$, Masafumi Toyoshima ${ }^{2}$, Nobuo Yaegashi $^{2}$ and Satoru Nagase ${ }^{1}$

\footnotetext{
${ }^{1}$ Department of Obstetrics and Gynecology, Yamagata University School of Medicine, Iidanishi, Yamagata 990-9585, Japan

${ }^{2}$ Department of Obstetrics and Gynecology, Tohoku University Graduate School of Medicine, Iidanishi, Yamagata 990-9585, Japan
}

Correspondence to: Manabu Seino, email: m-seino@med.id.yamagata-u.ac.jp

Keywords: endometrial cancer; uterine serous carcinoma; metabolomic analysis; paclitaxel

Received: September 20, $2017 \quad$ Accepted: July 12, $2018 \quad$ Published: August 10, 2018

Copyright: Seino et al. This is an open-access article distributed under the terms of the Creative Commons Attribution License 3.0 (CC BY 3.0), which permits unrestricted use, distribution, and reproduction in any medium, provided the original author and source are credited.

\section{ABSTRACT}

Introduction: Uterine serous carcinoma (USC) is more aggressive than other subtypes of endometrial carcinoma and is associated with a poor prognosis. We analyzed the metabolomic profile of USC with acquired resistance to paclitaxel.

Results: Glutathione (GSH) concentration in PTX-1 cells was higher than in USPC1 cells. In addition, GSH concentration in the USPC-1 cells increased after treatment with paclitaxel but was unchanged in PTX-1 cells. Glucose-6-phosphate (G6P) and ribose-5-phosphate (R5P) concentrations in PTX-1 cells were higher than those in USPC-1 cells. G6P concentration in the USPC-1 cells was unchanged after treatment with paclitaxel, while it decreased in PTX-1 cells.

Conclusion: Our results indicate that increased GSH and glucose metabolism may be related to acquiring resistance to paclitaxel in USC and thus may be targets for anti-USC therapy.

Materials and Methods: We compared metabolic profiles and reactions to paclitaxel in both a wild type USC cell line (USPC-1) and PTX-1, a cell line derived from USPC-1 which acquired paclitaxel resistance, using a capillary electrophoresis CE-MS/MS system.

\section{INTRODUCTION}

Endometrial carcinoma is a common gynecologic malignancy in women. Most endometrial cancers are classified as early stage and low grade (i.e., endometrioid carcinoma grade 1,2 ), with a 5 -year survival of greater than $85 \%$ [1]. However, the rare histologic type uterine serous carcinoma (USC) is more aggressive than other subtypes and is associated with a poor prognosis. The proportion of USC is less than $10 \%$ of all subtypes of endometrial carcinoma, but the 5-year survival of USC is poor with only $18-27 \%$, compared to that of low-grade types [1-3]. Type I endometrial carcinomas comprise endometrioid carcinomas (grade 1,2), are usually seen in younger patients, and are associated with obesity, hyperlipidemia, and hyperestrogenism. In contrast, Type II endometrial carcinomas include serous carcinoma and clear cell carcinoma, are seen in older patients, and are not associated with hormonal factors.

As many as $37-70 \%$ of USC cases showed extrauterine disease at time of diagnosis $[4,5]$, sometimes with scant or no myometrial invasion [6, 7]. Most cases of USC relapse after initial treatment, like epithelial ovarian serous carcinomas. The rate of recurrence is estimated to be $31-80 \%[4,8,9]$. Some studies suggested a beneficial role for adjuvant chemotherapy in USC even when diagnosed at an early stage [10-12]. However, many cases with USC received chemotherapy (paclitaxel/carboplatin) and as in cases of ovarian cancer, some acquired resistance to chemotherapy and had poor prognosis. Tubulin- $\beta$-III 
overexpression is a marker for poor prognosis after platinum/ taxane chemotherapy [13], but other mechanisms leading to chemoresistance in USC are unclear.

Metabolomic analysis is a new technique for evaluation of biological specimens to reveal various metabolic pathways. Metabolites are the end products of metabolic pathways and may be involved in various tumor features. Targeting metabolic enzymes from key metabolic pathways, like glucose metabolism, glutaminolysis and fatty acid synthesis, has been shown to enhance the cytotoxicity of various chemotherapeutic agents. It may be possible to improve the outcomes of chemoresistant tumors significantly by metabolite analysis $[14,15]$.

A metabolomic approach revealed parts of the mechanism for platinum resistance in ovarian cancer [16], but there has been no metabolomics study concerning USC specifically.

In many advanced cases of USC, chemotherapeutic agents including paclitaxel were administered, and some cases acquired resistance to repeated chemotherapy. We thus performed metabolomic analysis of USC cells with acquired resistance to paclitaxel. Our data suggest that both glutathione and glucose metabolism may play a role in the resistance of USC to paclitaxel.

\section{RESULTS}

\section{Metabolomic analysis of USC cells}

We first confirmed resistance to paclitaxel in USPC-1 and PTX-1 cells and found that PTX-1 cells were significantly resistant to paclitaxel compared to
USPC-1 cells (Figure 1). The proportion of PTX-1 cells in the $\mathrm{G} 2 / \mathrm{M}$ phase was greater than that of USPC-1 cells (Supplementary Figure 1).

Next, we performed metabolomic analysis of USPC1 and PTX-1 cells. The metabolic pathways assessed were glycolysis and pentose phosphate pathway, tricarboxylic acid cycle, urea cycle, the polyamine creatine metabolic pathway, purine metabolism, methionine cycle, glutathione (GSH) cycle, branched chain amino acid metabolism, lysine, tryptophan and nicotinamide metabolism, choline and fat metabolism.

In our analysis, we focused lipid metabolism, polyamine and creatine metabolism, methionine cycle, glutathione (GSH) metabolism and glucose metabolism. Malonyl-coenzyme-A ( $\mathrm{CoA})$ concentration in the lipid metabolism of USPC-1 cells, but not PTX-1 cells, was elevated after treatment with paclitaxel (Figure 2). Similarly, creatine, phosphocreatine and creatinine concentrations were also elevated in USPC-1 cells, but not PTX-1 cells, after treatment with paclitaxel (Figure 3). Methionine concentration in USPC-1 cells is elevated after paclitaxel treatment, but not in PTX-1 cells (Figure 4). Methionine concentration in the PTX-1 cells after paclitaxel treatment was significantly higher than that of USPC-1 cells. Additionally, cystathionine levels in PTX-1 cells were significantly lower than those in USPC-1 cells after paclitaxel treatment.

GSH is a tripeptide consisting of glutamic acid, cysteine and glycine. Cysteine and GSH concentrations in PTX-1 cells were higher than in USPC-1 cells (Table 1, Figure 5). GSH concentration in the USPC-1 cells increased after paclitaxel treatment but was unchanged in

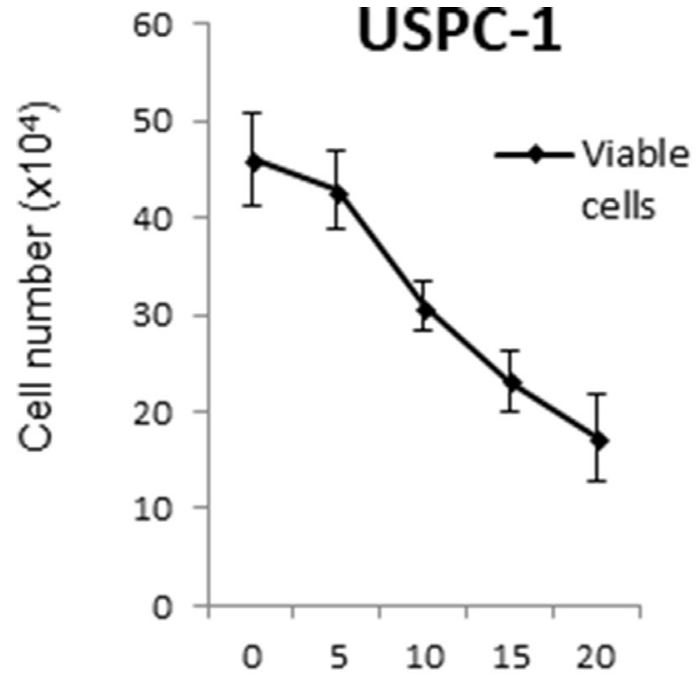

Pacliaxel (nM)

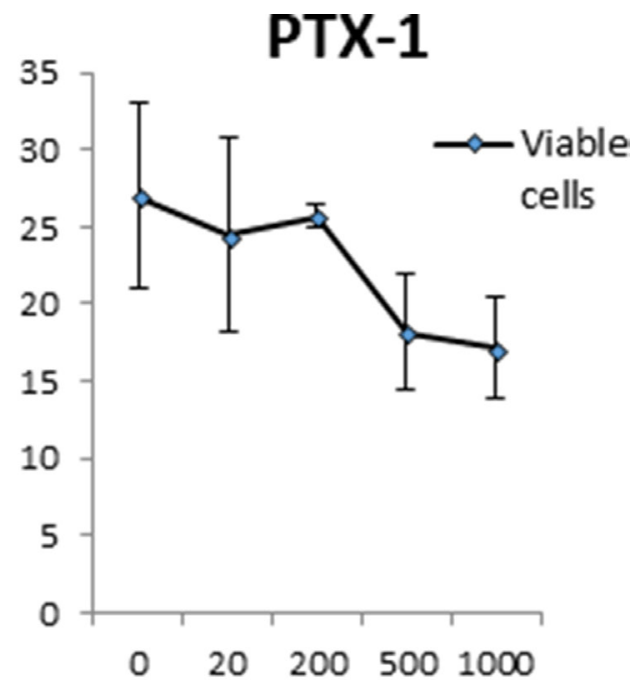

Pacliaxel (nM)

Figure 1: Growth inhibition of uterine serous carcinoma cells after treatment with paclitaxel. USPC-1 and PTX-1 cells were treated with the indicated concentrations of paclitaxel for $24 \mathrm{~h}$. Then the number of viable cells was determined for each cell line. The $\mathrm{IC}_{50}$ concentration was calculated using the formula described in Materials and Methods. Values in the graphs represent the means \pm SD of three independent experiments. 
PTX-1 cells (Table 1, Figure5). This indicates that GSH may be related to paclitaxel resistance. In addition, the glutathione redox ratio (GSH/GSSG) in USPC-1 cells was unchanged, but was significantly elevated after paclitaxel treatment in PTX-1 cells (Table 1, Figure 5).

Next, we studied glucose metabolism in both cell lines. Glucose-6-phosphate (G6P) concentration in PTX-1 cells was higher than in USPC-1 cells (Table 2, Figure 6). G6P concentration in the USPC-1 cells was unchanged by paclitaxel treatment while it decreased in PTX-1 cells (Table 2, Figure 6). In the Pentose pathway, ribose-5-phosphate (R5P) and phosphoribosyl diphosphate (PRPP) concentrations in PTX-1 cells were higher than those in USPC-1 cells (Table 2, Figure 7). To examine glucose consumption in USC cells, we performed oxygen consumption tests in USPC-1 and PTX-1 cells. After about $60 \mathrm{~min}$ until treatment with the reagent, oxygen consumption in PTX-1 cells was higher than that in USPC-1 cells (Figure 9A). Additionally, GLUT1 expression in PTX-1 cells was higher than that in USPC-1 cells (Figure 9B). Finally, 2-oxoglutarate levels in USPC-1 cells were higher than in PTX-1 cells, and the ratio of glucose to 2-oxoglutarate in USPC-1 cells was lower than that in PTX-1 (Figure 8).

\section{DISCUSSION}

USC is one of the most malignant types of gynecological malignancies. Most cases of USC relapse after the initial treatment, like epithelial ovarian serous carcinomas. Some studies suggested a beneficial role of adjuvant chemotherapy for USC even when diagnosed at an early stage [10-12]. We analyzed metabolites in USC cells to reveal the mechanisms of acquired resistance to paclitaxel.

Lipid metabolism is associated with cancer and particularly free fatty acids may be involved in the development of cancer [17]. Abnormal free fatty acid
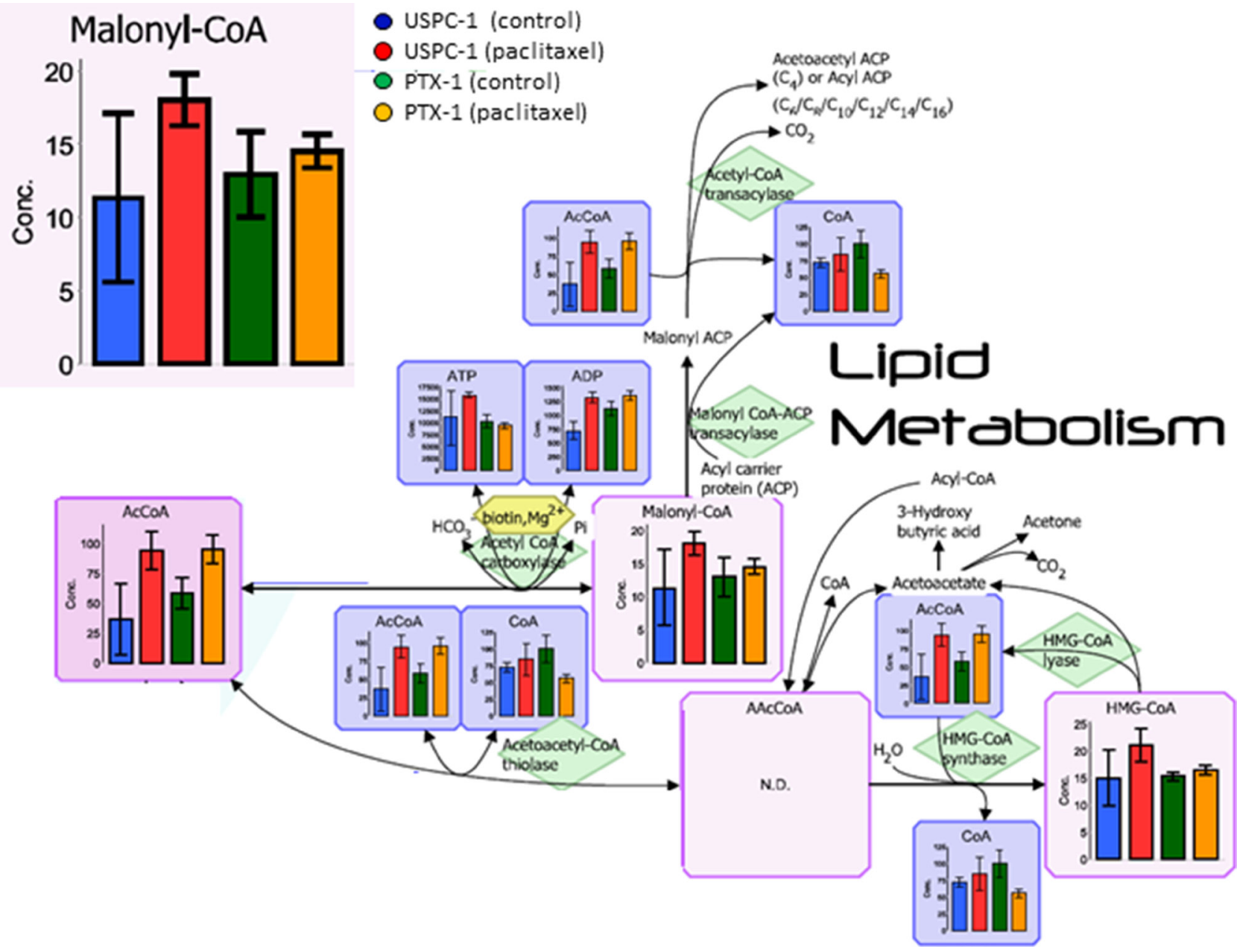

Figure 2: Lipid metabolism analysis after treatment with paclitaxel in uterine serous carcinoma cells. Each cell line was treated with $15 \mathrm{nM}$ paclitaxel or control vehicle for $24 \mathrm{~h}$. Blue bars represent USPC-1 cells (control), red bars represent USPC-1 cells treated with paclitaxel, green bars represent PTX-1 cells (control) and yellow bars represent PTX-1 cells treated with paclitaxel. Values in the graphs represent the means $\pm \mathrm{SD}$ of three independent experiments. ${ }^{*} P<0.05$. N.D.: not detected. 
synthesis is among the prevalent features of various cancers, including ovarian cancer [18]. Malonyl-CoA in fatty acid synthesis mediates cell death in breast cancer cells [19]. In this analysis, malonyl-CoA levels in the paclitaxel sensitive USPC-1 cells are elevated after paclitaxel treatment. This result indicates that in USC cells, malonyl-CoA may be associated with paclitaxelinduced cell death.

It is known that creatinine kinase $(\mathrm{CK})$ is related to sarcoma development. CK expression is decreased in malignant tissue compared to normal tissue [20]. Additionally, CK regulates the cell cycle in cancer
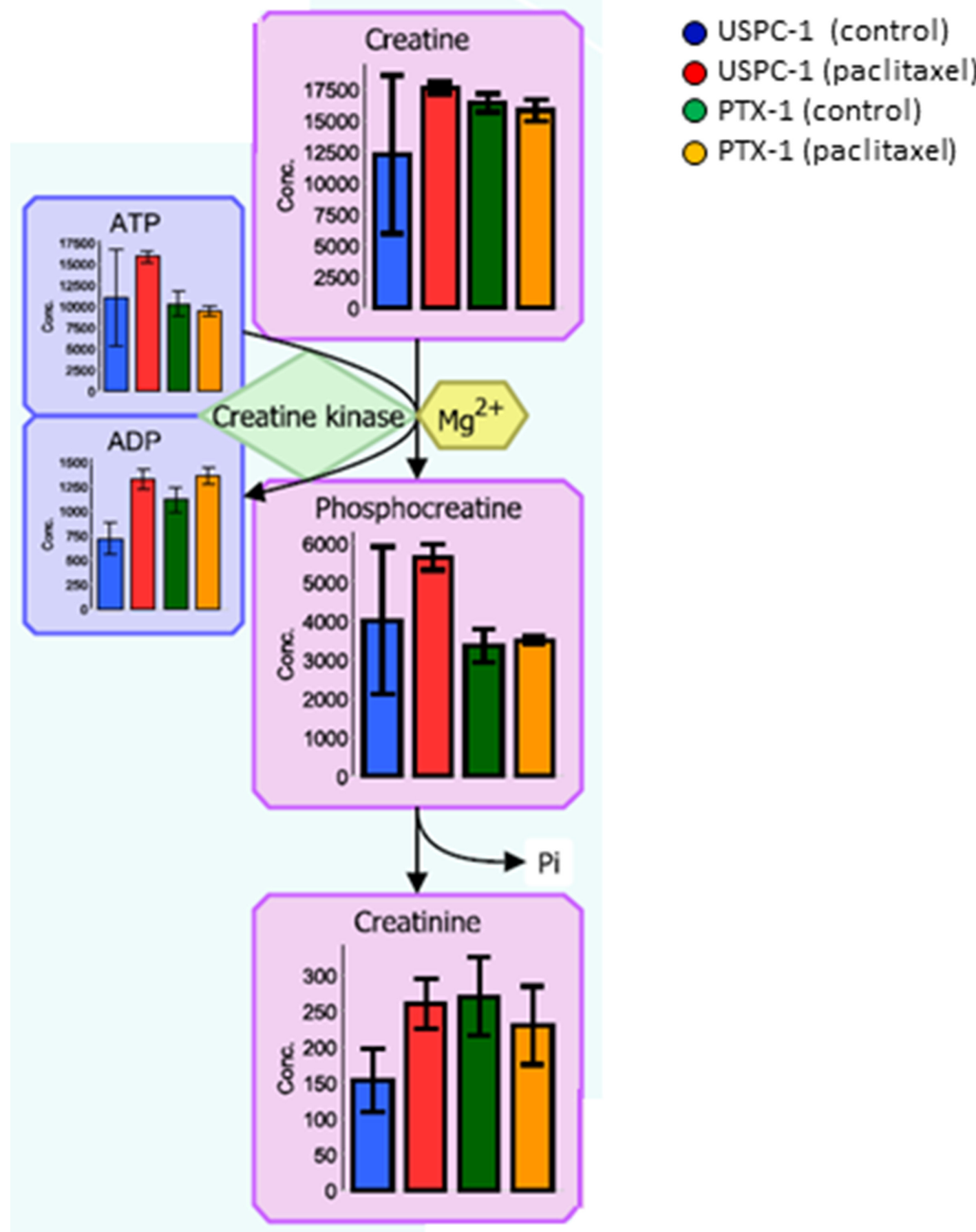

Figure 3: Creatine metabolism analysis after treatment with paclitaxel in uterine serous carcinoma cells. Each cell line was treated with $15 \mathrm{nM}$ paclitaxel or control vehicle for $24 \mathrm{~h}$. Blue bars represent USPC-1 cells (control), red bars represent USPC-1 cells treated with paclitaxel, green bars represent PTX-1 cells (control) and yellow bars represent PTX-1 cells treated with paclitaxel. Values in the graphs represent the means $\pm \mathrm{SD}$ of three independent experiments. ${ }^{*} P<0.05$. 
cells [21]. Our study indicates that creatinine kinase is relevant for paclitaxel resistance, because the creatine concentration in the paclitaxel resistant cells is higher than in sensitive cells.

Methionine plays important roles in cancer cells by regulating cell death and survival [22], as well as metastasis in breast cancer [23]. Our data show that the methionine concentration in PTX-1 cells was higher than that in
USPC-1 cells, and methionine levels were elevated after treatment by paclitaxel in USPC-1 cells. This indicates that methionine concentration is elevated after paclitaxel treatment and is associated with paclitaxel resistance. Cystathionine beta synthase is generally associated with drug resistance, including resistance to anti-tumor agents $[24,25]$. In this analysis, cystathionine was elevated after paclitaxel treatment in USPC-1 cells, but not in PTX-1
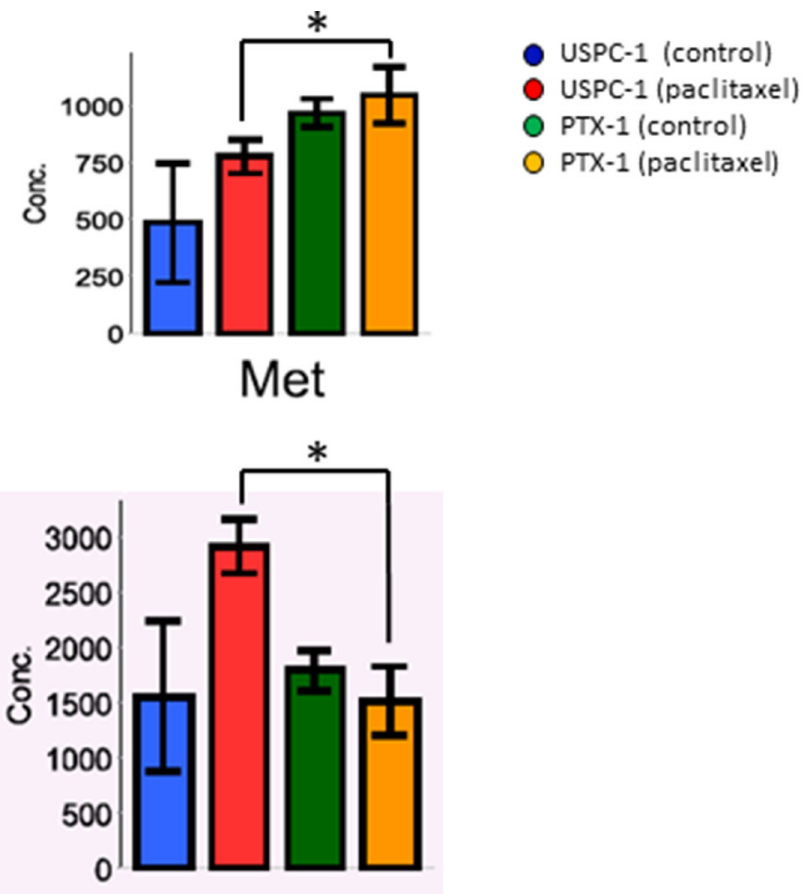

Cystathionine

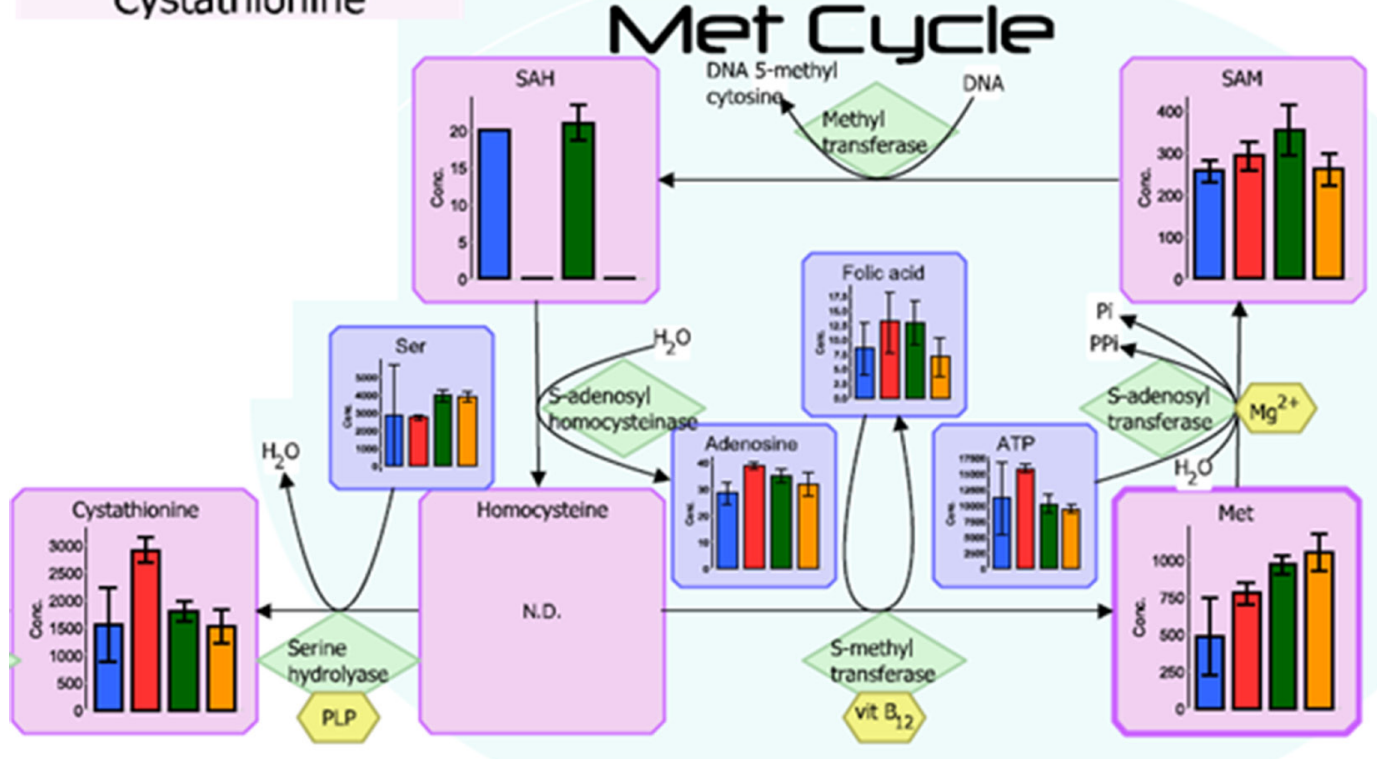

Figure 4: Methionine metabolism analysis after treatment with paclitaxel in uterine serous carcinoma cells. Each cell line was treated with $15 \mathrm{nM}$ paclitaxel or control vehicle for $24 \mathrm{~h}$. Blue bars represent USPC-1 cells (control), red bars represent USPC-1 cells treated with paclitaxel, green bars represent PTX-1 cells (control) and yellow bars represent PTX-1 cells treated with paclitaxel. Values in the graphs represent the means $\pm \mathrm{SD}$ of three independent experiments. ${ }^{*} P<0.05$. N.D.: not detected. 
Table 1: Concentration of metabolites about glutathione metabolic pathways in USC cells

\begin{tabular}{|c|c|c|c|c|c|c|c|c|c|c|c|c|c|c|c|c|}
\hline \multirow{3}{*}{ Compound name } & \multicolumn{8}{|c|}{ Concentration $\left(\mathrm{pmol} / 10^{6}\right.$ cells) } & & & & & & & & \\
\hline & \multicolumn{2}{|c|}{$\begin{array}{c}\text { USPC- } \\
\text { 1(Control) }\end{array}$} & \multicolumn{2}{|c|}{$\begin{array}{c}\text { USPC- } \\
\text { 1(Paclitaxel) }\end{array}$} & \multicolumn{2}{|c|}{$\begin{array}{c}\text { PTX- } \\
\text { 1(Control) }\end{array}$} & \multicolumn{2}{|c|}{$\begin{array}{c}\text { PTX- } \\
\text { 1(Paclitaxel) }\end{array}$} & \multicolumn{2}{|c|}{$\begin{array}{c}\text { USPC- } \\
\text { 1(Paclitaxel) vs } \\
\text { USPC-1(Control) }\end{array}$} & \multicolumn{2}{|c|}{$\begin{array}{c}\text { PTX- } \\
\text { 1(Paclitaxel) vs } \\
\text { PTX-1(Control) }\end{array}$} & \multicolumn{2}{|c|}{$\begin{array}{c}\text { PTX-1(Control) } \\
\text { vs USPC- } \\
\text { 1(Control) }\end{array}$} & \multicolumn{2}{|c|}{$\begin{array}{c}\text { PTX-1(Paclitaxel) } \\
\text { vs USPC- } \\
\text { 1(Paclitaxel) }\end{array}$} \\
\hline & Mean & S.D. & Mean & S.D. & Mean & S.D. & Mean & S.D. & Ratio & $P$ value & Ratio & $P$ value & Ratio & $P$ value & Ratio & $P$ value \\
\hline Folic acids & 8.5 & 4.5 & 13 & 5.2 & 13 & 3.8 & 7.1 & 3.3 & 1.5 & 0.313 & 0.5 & 0.113 & 1.5 & 0.261 & 0.5 & 0.178 \\
\hline ADP & 716 & 159 & 1,319 & 98 & 1,118 & 125 & 1,364 & 89 & 1.8 & $0.009^{*}$ & 1.2 & 0.056 & 1.6 & $0.029^{*}$ & 1.0 & 0.588 \\
\hline ATP & 11,072 & 5,718 & 15,846 & 651 & 10,294 & 1,417 & 9,452 & 631 & 1.4 & 0.284 & 0.9 & 0.422 & 0.9 & 0.838 & 0.6 & $2.6 \mathrm{E}-04^{*}$ \\
\hline Gly & 11,954 & 4,697 & 16,374 & 245 & 16,379 & 1,012 & 15,489 & 914 & 1.4 & 0.244 & 0.9 & 0.322 & 1.4 & 0.241 & 0.9 & 0.231 \\
\hline Cys & 436 & 482 & 519 & 251 & 1,796 & 262 & 1,950 & 304 & 1.2 & 0.851 & 1.1 & 0.545 & 4.1 & 0.112 & 3.8 & $0.004^{*}$ \\
\hline Glu & 64,248 & 16,387 & 83,494 & 2,271 & 75,376 & 3,081 & 65,793 & 4,357 & 1.3 & 0.177 & 0.9 & $0.041^{*}$ & 1.2 & 0.360 & 0.8 & $0.008^{*}$ \\
\hline $\begin{array}{l}\text { Glutathione } \\
\text { (GSSG) }\end{array}$ & 1,679 & 402 & 2,208 & 239 & 2,158 & 352 & 1,480 & 123 & 1.3 & 0.138 & 0.7 & 0.066 & 1.3 & 0.197 & 0.7 & $0.019^{*}$ \\
\hline $\begin{array}{l}\text { Glutathione } \\
\text { (GSH) }\end{array}$ & 13,828 & 5,374 & 20,770 & 138 & 21,282 & 1,894 & 19,231 & 760 & 1.5 & 0.155 & 0.9 & 0.193 & 1.5 & 0.126 & 0.9 & 0.068 \\
\hline NADPH/NADP+ & N.A. & N.A. & N.A. & N.A. & N.A. & N.A. & N.A. & N.A. & N.A. & N.A. & N.A. & N.A. & N.A. & N.A. & N.A. & N.A. \\
\hline
\end{tabular}

S.D.; standard deviation, ADP; adenosine diphosphate, ATP; adenosine triphosphate, NADPH; reduced nicotinamide adenine dinucleotide phosphate, NADP; nicotinamide adenine dinucleotide phosphate, ${ }^{*} P<0.05$, N.A.; not available

cells. This suggests that cystathionine beta synthase in the USPC-1 cells was activated via pathways for expelling paclitaxel. On the other hand, cystathionine levels in PTX1 cells did not change. We speculate that PTX-1 cells may expel paclitaxel via other mechanisms or that paclitaxel intake in PTX-1 cells may be blocked.

Glucose metabolism may also have important roles in the sensitivity of cancer cells to chemotherapeutics. It has been shown that cancer cells increase glucose uptake and glycolysis [26]. Therefore, the glucose metabolic pathway in cancer cells may be a target for cancer therapy [27]. Glucose is taken up into cells via the glucose transporter and is subsequently phosphorylated by hexokinase. We demonstrated that G6P and R5P concentrations in paclitaxel-resistant cells were higher than those in paclitaxel-sensitive cells; glucose consumption and GLUT1 expression in resistant cells were higher than those in sensitive cells. Cancer cells have been shown to shift their energy production from the oxidative phosphorylation pathway to glycolysis, known as the Warburg effect [28]. In contrast, it was reported that not all tumors shift to glycolysis for energy production; some diffuse large B-cell lymphomas and glioblastomas remain dependent on oxidative phosphorylation for energy production $[29,30]$. Interestingly, oxidative phosphorylation and GLUT1 expression in ovarian cancer cells with acquired resistance were higher than those in sensitive cells. It was reported that cells with acquired resistance exhibited a high metabolically active phenotype with the ability to switch between oxidative phosphorylation and glycolysis compared with sensitive cells [31]. Our data show that glucose use shifts metabolism toward more oxidative phosphorylation and mitochondrial function in paclitaxelresistant cells, and some studies reported the importance of mitochondrial function in enabling therapeutic resistance [32]. It is suggested that mitochondrial function may be a new therapeutic target in paclitaxel-resistant cells. In addition, 2-oxoglutarate (2-OG) is being produced from glutamic acid (Glu) via various amino acid metabolic pathways. Particularly, the ratio of Glu/2-OG is indicative for amino acid synthesis and degradation. The amino acid metabolism of paclitaxel resistant cells may be more activated than that of sensitive cells.

The concentration of glutathione in the paclitaxelresistant cells was higher than that in paclitaxel-sensitive cells. GSH is a tripeptide consisting of glutamate, cysteine, and glycine. The GSH concentration in cancer cells is regulated by the cysteine transporter $\mathrm{xCT}$ [33]. $\mathrm{xCT}$ is stabilized by a variant form of CD44 which is associated with cancer stem cells [34]. GSH is one of the main antioxidants in cancer cells. Reactive oxygen species (ROS) are being produced by anticancer agents in cancer cells and can induce apoptosis [35]. As an antioxidant, GSH prevents the increase of ROS in cancer cells. We hypothesize that GSH prevents apoptosis induced by paclitaxel in paclitaxel resistant cells. In addition, the glutathione redox ratio (GSH/GSSG) indicates the oxidative stress status in cancer cells. With increasing oxidative stress in the cells, the ratio of GSH/GSSG decreases. In this study, the GSH/GSSG ratio in the paclitaxel sensitive cells was unchanged after paclitaxel treatment, but was elevated in the paclitaxel resistant cells. This result suggests that paclitaxel resistant cells have the ability to detoxify oxidative stress.

Many studies reported metabolomic analysis of various cancers, including ovarian cancer [16]. This is a very important avenue of research that may reveal specifically the reaction to anticancer agents and alterations of signaling pathways useful for cancer therapy. Metabolomic profiling analysis is a powerful tool to understand the biological pathways of cancer cells, and could detect organ- or cellspecific changes easily. However, the results might contain junk data, so it is necessary to verify the results from metabolomic profiling analysis. We focused on GSH and 


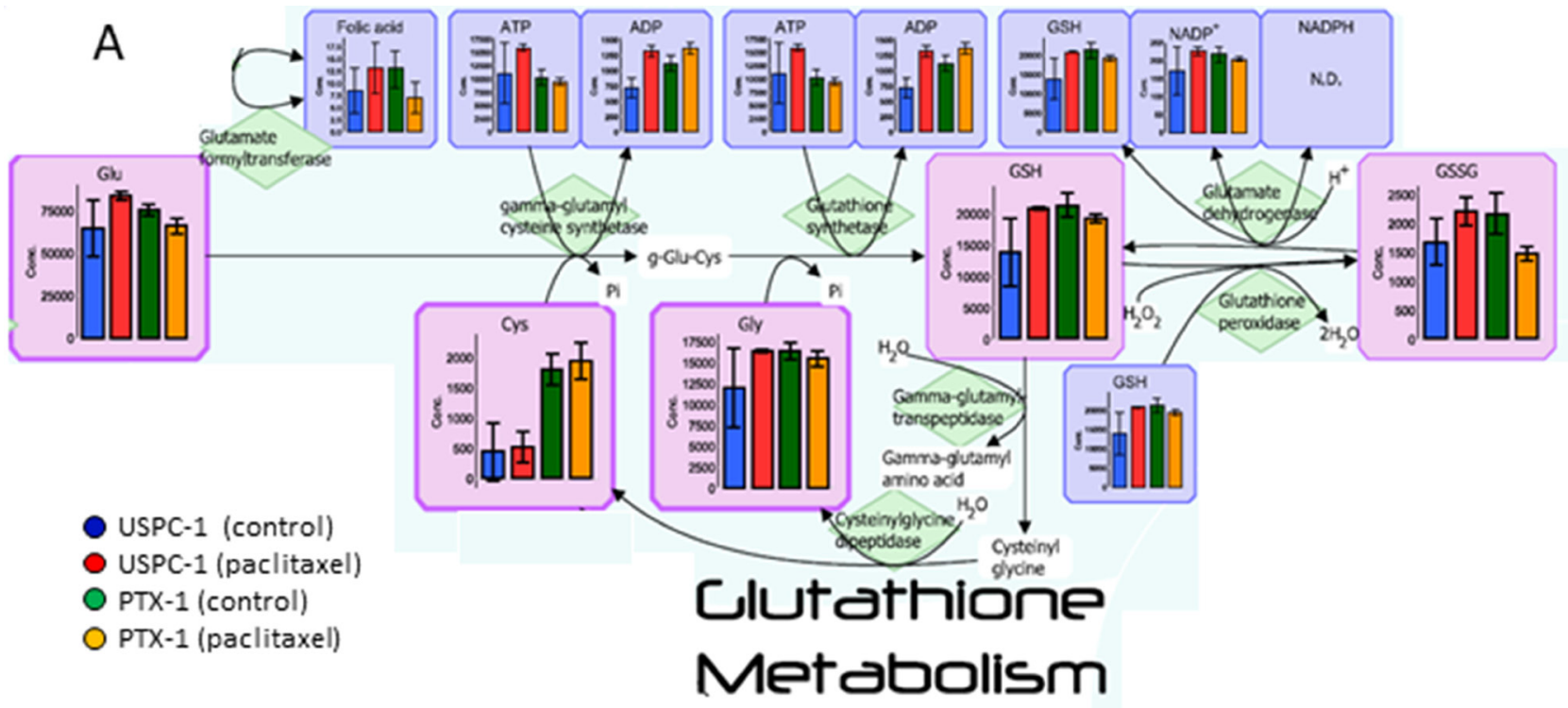

B Cys

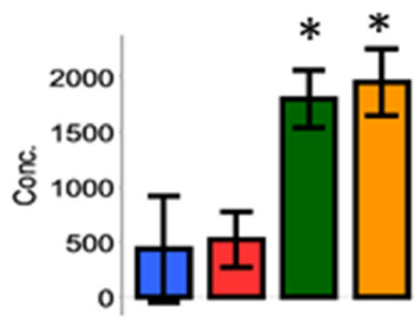

GSH

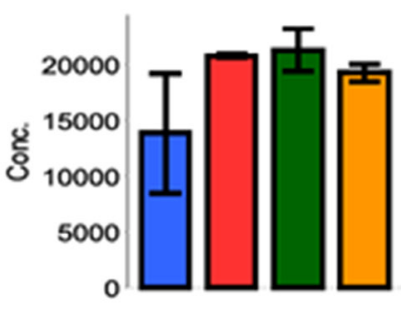

GSSG
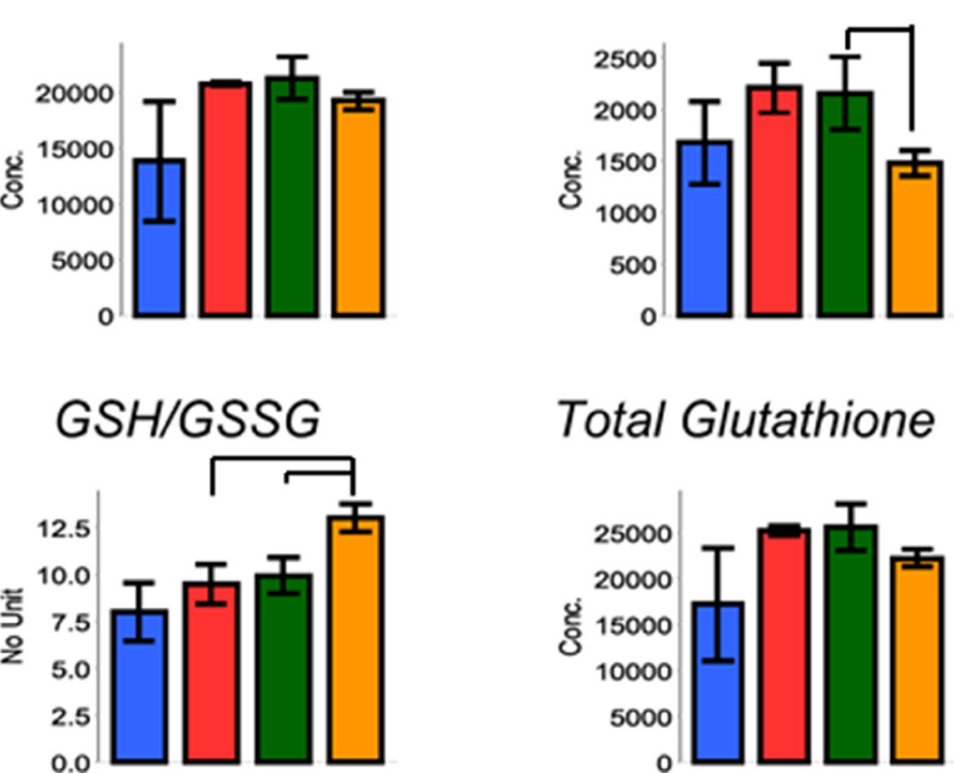

Total Glutathione

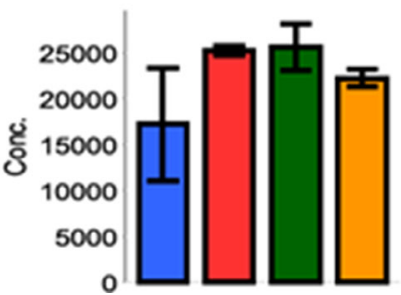

Figure 5: Glutathione (GSH) metabolism analysis after treatment with paclitaxel in uterine serous carcinoma cells. (A) Each cell line was treated with $15 \mathrm{nM}$ paclitaxel or control vehicle for $24 \mathrm{~h}$. Blue bars represent USPC-1 cells (control), red bars represent USPC-1 cells treated with paclitaxel, green bars represent PTX-1 cells (control) and yellow bars represent PTX-1 cells treated with paclitaxel. Values in the graphs represent the means \pm SD of three independent experiments. (B) Concentrations of cysteine, GSH, GSSG and total glutathione in USC cells after treatment with paclitaxel. GSH/GSSG (glutathione redox ratio) $=[\mathrm{GSH}] /[\mathrm{GSSG}]$. Total glutathione $=[\mathrm{GSH}]+2 \times[\mathrm{GSSG}],{ }^{*} P<0.05$. N.D.: not detected. 
glycolysis from our data because these are associated with chemoresistance, include cancer stem cells [27, 34]. We are currently researching the GSH mechanism that confers chemoresistance in USC cells. We think metabolomic analysis is very important for seizing opportunities for cancer therapies, and this study is the beginning of comprehending

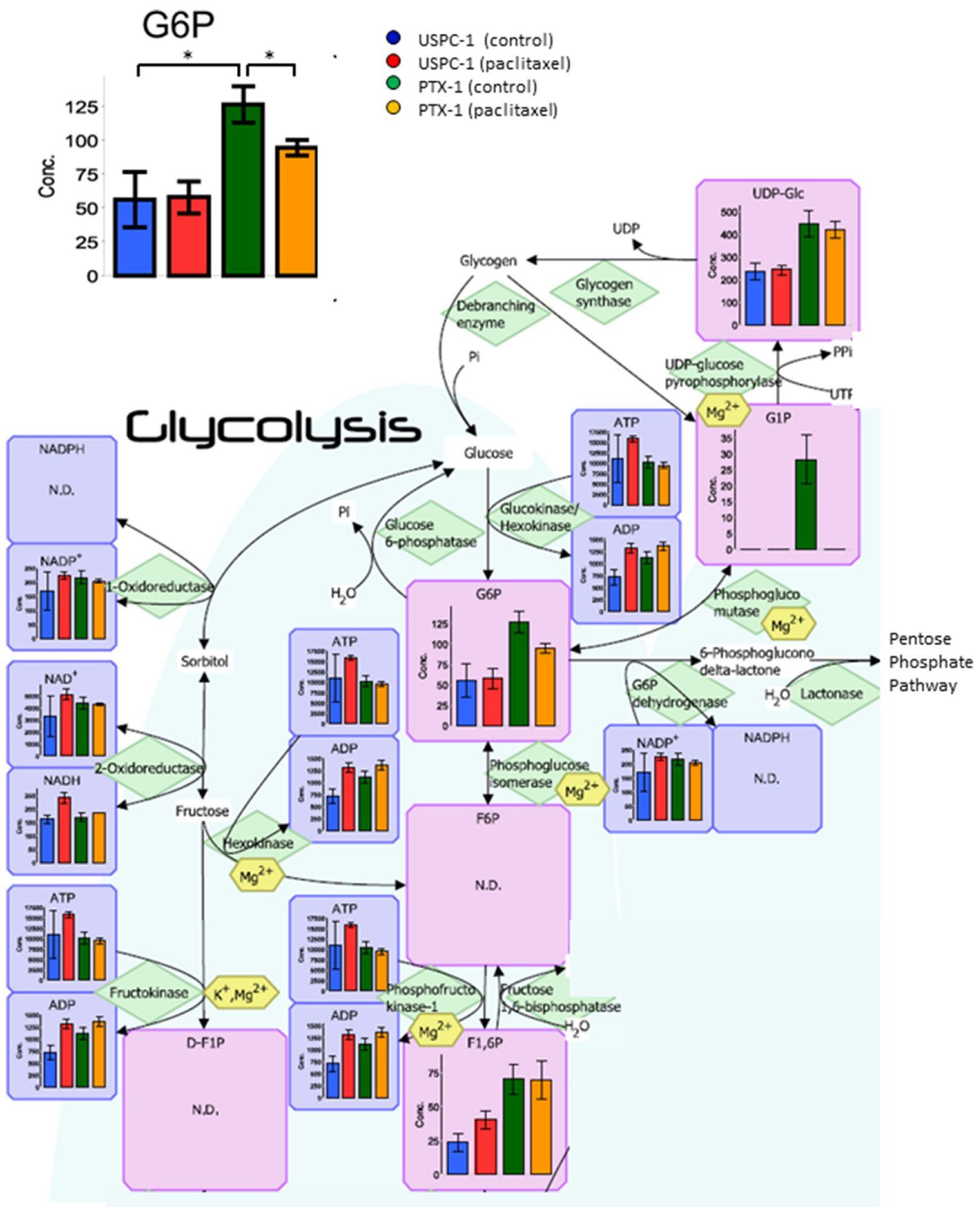

Figure 6: Analysis of the glycolytic pathway after treatment with paclitaxel in uterine serous carcinoma cells. Each cell line was treated with $15 \mathrm{nM}$ paclitaxel or control vehicle for $24 \mathrm{~h}$. Blue bars represent USPC-1 cells (control), red bars represent USPC1 cells treated with paclitaxel, green bars represent PTX-1 cells (control) and yellow bars represent PTX-1 cells treated with paclitaxel. Values in the graphs represent the means \pm SD of three independent experiments. ${ }^{*} P<0.05$. N.D.: not detected. 
Table 2: Concentration of metabolites about glycolysis in USC cells

\begin{tabular}{|c|c|c|c|c|c|c|c|c|c|c|c|c|c|c|c|c|}
\hline \multirow{3}{*}{ Compound name } & \multicolumn{16}{|c|}{ Concentration $\left(\mathrm{pmol} / 10^{6}\right.$ cells) } \\
\hline & \multicolumn{2}{|c|}{ USPC-1(Control) } & \multicolumn{2}{|c|}{$\begin{array}{c}\text { USPC- } \\
\text { 1(Paclitaxel) }\end{array}$} & \multicolumn{2}{|c|}{$\begin{array}{c}\text { PTX- } \\
\text { 1(Control) }\end{array}$} & \multicolumn{2}{|c|}{$\begin{array}{c}\text { PTX- } \\
\text { 1(Paclitaxel) }\end{array}$} & \multicolumn{2}{|c|}{$\begin{array}{c}\text { USPC- } \\
1 \text { (Paclitaxel) } \\
\text { vs USPC- } \\
1 \text { (Control) }\end{array}$} & \multicolumn{2}{|c|}{$\begin{array}{c}\text { PTX- } \\
\text { 1(Paclitaxel) vs } \\
\text { PTX-1(Control) }\end{array}$} & \multicolumn{2}{|c|}{$\begin{array}{c}\text { PTX-1(Control) } \\
\text { vs USPC- } \\
\text { 1(Control) }\end{array}$} & \multicolumn{2}{|c|}{$\begin{array}{c}\text { PTX- } \\
\text { 1(Paclitaxel) } \\
\text { vs USPC- } \\
\text { 1(Paclitaxel) }\end{array}$} \\
\hline & Mean & S.D. & Mean & S.D. & Mean & S.D. & Mean & S.D. & Ratio & $P$ value & Ratio & $P$ value & Ratio & $P$ value & Ratio & $P$ value \\
\hline NAD+ & 3,308 & 1,684 & 5,126 & 463 & 4,368 & 509 & 4,322 & 81 & 1.5 & 0.197 & 1.0 & 0.890 & 1.3 & 0.392 & 0.8 & 0.091 \\
\hline NADH & 162 & 15 & 241 & 19 & 169 & 14 & 184 & N.A. & 1.5 & $0.006^{*}$ & 1.1 & N.A. & 1.0 & 0.598 & 0.8 & N.A. \\
\hline UDP-glucose & 235 & 39 & 244 & 21 & 446 & 58 & 420 & 38 & 1.0 & 0.756 & 0.9 & 0.560 & 1.9 & $0.009^{*}$ & 1.7 & $0.005^{*}$ \\
\hline G6P & 56 & 20 & 58 & 12 & 126 & 13 & 94 & 5.8 & 1.0 & 0.898 & 0.7 & $0.037^{*}$ & 2.3 & $0.001^{*}$ & 1.6 & $0.019^{*}$ \\
\hline F1, 6P & 24 & 6.4 & 40 & 6.9 & 70 & 11 & 70 & 14 & 1.7 & $0.036^{*}$ & 1.0 & 0.980 & 3.0 & $0.006^{*}$ & 1.7 & 0.050 \\
\hline ADP & 716 & 159 & 1,319 & 98 & 1,118 & 125 & 1,364 & 89 & 1.8 & $0.009^{*}$ & 1.2 & 0.056 & 1.6 & $0.029^{*}$ & 1.0 & 0.588 \\
\hline GTP & 1,815 & 707 & 2,550 & 90 & 2,059 & 280 & 1,998 & 28 & 1.4 & 0.212 & 1.0 & 0.740 & 1.1 & 0.622 & 0.8 & $0.005^{*}$ \\
\hline ATP & 11,072 & 5,718 & 15,846 & 651 & 10,294 & 1,417 & 9,452 & 631 & 1.4 & 0.284 & 0.9 & 0.422 & 0.9 & 0.838 & 0.6 & 2.6E- $04^{*}$ \\
\hline NADPH/NADP+ & N.A. & N.A. & N.A. & N.A. & N.A. & N.A. & N.A. & N.A. & N.A. & N.A. & N.A. & N.A. & N.A. & N.A. & N.A. & N.A. \\
\hline NADH/NAD+ & 0.06 & 0.04 & 0.05 & $0.008^{*}$ & 0.04 & 0.005 & 0.04 & N.A. & 0.8 & 0.591 & 1.1 & N.A. & 0.6 & 0.426 & 0.9 & N.A. \\
\hline G6P/R5P & 17 & N.A. & 89 & N.A & 15 & 2.9 & 29 & 15 & 5.1 & N.A. & 2.0 & 0.236 & 0.9 & N.A. & 0.3 & N.A. \\
\hline
\end{tabular}

NAD; nicotinamide adenine dinucleotide, NADH; reduced nicotinamide adenine dinucleotide, G6P; glucose 6-phosphate, F1, 6P; fluctose 1,6-diphosphate, R5P; ribose

5-phosphate, NADPH; reduced nicotinamide adenine dinucleotide phosphate, NADP; nicotinamide adenine dinucleotide phosphate, S.D.; standard deviation, ${ }^{*} P<0.05$, N.A.; not available.

the reaction of USC cells to paclitaxel, and identifying new molecular targets for therapy. This method is useful for explorative investigations to detect new therapeutic targets.

Our study indicates that an increased GSH and glucose metabolism may be relevant for acquiring resistance to paclitaxel in USC cells and thus these may be targets for anti-USC therapy.

\section{MATERIALS AND METHODS}

\section{Cell culture}

Human USC cell lines USPC-1 and PTX-1 were kindly provided by Dr. Santin, Department of Obstetrics and Gynecology, Division for Gynecologic Oncology at the Yale University School of Medicine (New Haven, CT, USA) [36]. PTX-1 was established from USPC-1 by maintaining the cells in medium with a low dose of paclitaxel for three months. The cells were maintained in RPMI1640 medium supplemented with $10 \%$ fetal bovine serum and

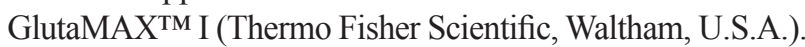
The culture medium was supplemented with $100 \mathrm{U} / \mathrm{ml}$ penicillin and $100 \mu \mathrm{l}$ streptomycin and changed every 3 days.

\section{Reagents}

Paclitaxel was purchased from Sigma-Aldrich (St. Louis, MO, USA) and dissolved in dimethyl sulfoxide (DMSO) to prepare a $10 \mathrm{mM}$ stock solution. D-mannitol and methanol were purchased from Wako (Osaka, Japan). Anti-glucose transporter 1 (GLUT1) antibody (sc-7903) was purchased from Santa Cruz Biotechnology, Inc. (Santa Cruz, CA, USA). Anti- $\beta$-actin antibody (A1978) was purchased from Sigma-Aldrich (St. Louis, MO, USA).

\section{Cell viability assay}

Viable and dead cells were identified by their ability and inability to retain trypan blue $[37,38]$. Cells were stained with $0.2 \%$ trypan blue, and the numbers of viable and dead cells were determined using a hemocytometer. Cell viability (\%) was defined as $100 \times$ (number of viable cells/number of total cells), whereas the percentage of dead cells was defined as $100 \times$ (number of dead cells/ number of total cells). To determine the $\mathrm{IC}_{50}$ values of paclitaxel for USPC-1 cells used in the present study, we treated the cells with varying concentrations of paclitaxel for $24 \mathrm{~h}$ and then determined their viability. The $\mathrm{IC}_{50}$ values were calculated using the following fomula [39]:

$\mathrm{IC}_{50}=10^{[\log (\mathrm{AB}) \times(50-\mathrm{C})][(\mathrm{D}-\mathrm{C})+\log (\mathrm{B})]}$ where $\mathrm{A}$ and $\mathrm{B}$ are the corresponding concentrations of the tested drug directly above and below 50\% inhibition, respectively, and $\mathrm{C}$ and $\mathrm{D}$ correspond to the percentage of inhibition directly below and above $50 \%$ inhibition, respectively.

\section{Metabolomic analysis}

Metabolomic analysis was performed by Human Metabolome Technologies (HMT Inc., Tsuruoka, Japan) as described previously [40]. The cells were treated with paclitaxel $(15 \mathrm{nM})$ for $24 \mathrm{~h}$. Metabolites were then extracted from 3-4.5 $\times 10^{6}$ cells with methanol containing Internal Standard Solution (HMT Inc., Tsuruoka, Japan) and analyzed using a capillary electrophoresis CE-MS/ MS system (HMT Inc., C-SCOPE). Culture medium was removed from a $10-\mathrm{cm}$ culture dish and cells were washed twice in $5 \%$ mannitol solution (first with $10 \mathrm{~mL}$ and then with $2 \mathrm{~mL}$ ) within $2 \mathrm{~min}$. Next, cells were treated with $800 \mu \mathrm{L}$ methanol for $30 \mathrm{~s}$ in order to inactivate enzymes, 
and $550 \mu \mathrm{L}$ Milli-Q water containing internal standards (H33304-1002, HMT Inc.) for another $30 \mathrm{~s}$. The extract was transferred into a microfuge tube and centrifuged at $2,300 \times g$ and $4^{\circ} \mathrm{C}$ for $5 \mathrm{~min}$. Then, the upper layer was centrifugally filtered through a Millipore $5-\mathrm{kDa}$ cutoff filter at $9,100 \times g$ and $4^{\circ} \mathrm{C}$ for $120 \mathrm{~min}$ to remove proteins. The filtrate was centrifugally concentrated and resuspended in $50 \mu \mathrm{L}$ of Milli-Q water. Peaks detected by CE-TOFMS and CE-MS/MS were extracted using automatic integration software (MasterHands, Keio University, Tsuruoka, Japan and MassHunter Quantitative Analysis B.04.00, Agilent Technologies, Santa Clara, CA, USA, respectively) [41]. The peaks were annotated with putative metabolites from the HMT metabolite database

A

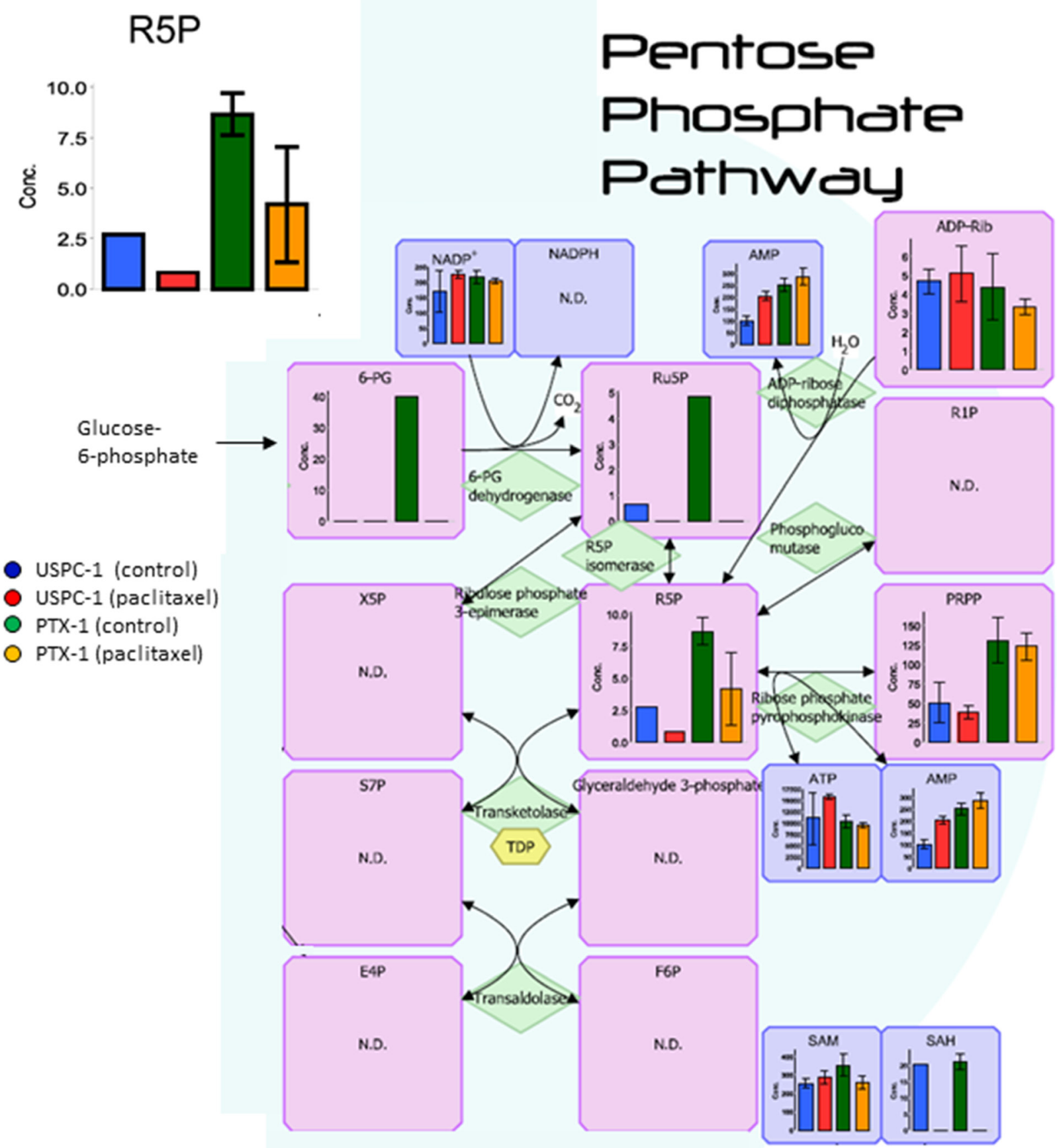

Figure 7: Analysis of the pentose phosphate pathway after treatment with paclitaxel in uterine serous carcinoma cells. Each cell line was treated with $15 \mathrm{nM}$ paclitaxel or control vehicle for $24 \mathrm{~h}$. Blue bars represent USPC-1 cells (control), red bars represent USPC-1 cells treated with paclitaxel, green bars represent PTX-1 cells (control) and yellow bars represent PTX-1 cells treated with paclitaxel. Values in the graphs represent the means $\pm \mathrm{SD}$ of three independent experiments. ${ }^{*} P<0.05$. N.D.: not detected. 


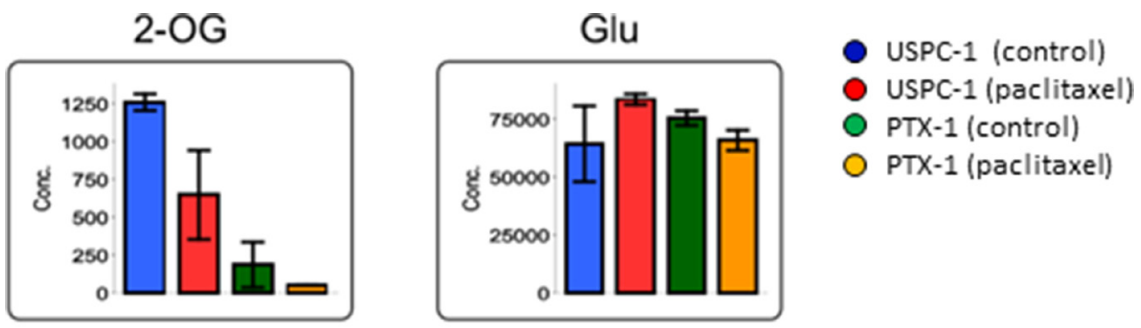

\section{Glu/2-Oxoglutarate}

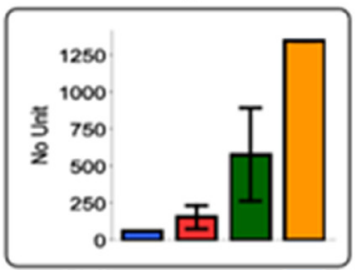

Figure 8: Concentration of 2-oxoglutarate (2-OG) and glutamic acid (Glu) after treatment with paclitaxel in uterine serous carcinoma cells. Each cell line was treated with $15 \mathrm{nM}$ paclitaxel or control vehicle for $24 \mathrm{~h}$. Blue bars represent USPC-1 cells (control), red bars represent USPC-1 cells treated with paclitaxel, green bars represent PTX-1 cells (control) and yellow bars represent PTX-1 cells treated with paclitaxel. Values in the graphs represent the means $\pm \mathrm{SD}$ of three independent experiments. ${ }^{*} P<0.05$.

A

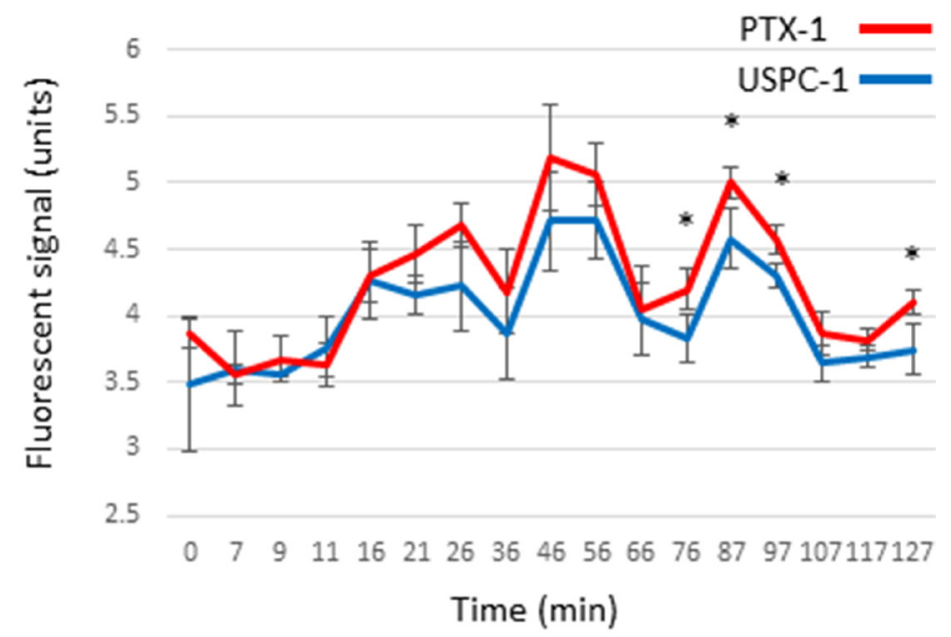

B

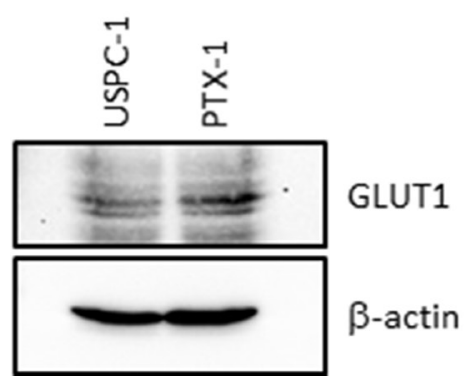

Figure 9: Glucose consumption and glucose transporter expression in uterine serous carcinoma cells. (A) Oxygen consumption assay. USPC-1 and PTX-1 cells were seeded in a 96-well plate at density of $8.0 \times 10^{4}$ cells. The plate was read using a fluorescence plate reader. The excitation and emission spectra were $380 \mathrm{~nm}$ and $650 \mathrm{~nm}$, respectively. The values in the graphs represent means \pm SD of three independent experiments. ${ }^{*} P<0.05$. (B) USPC-1 and PTX-1 cells were subjected to immunoblot analysis of GLUT1 and $\beta$-actin. 
based on their migration times (MTs) in CE and $m / z$ values determined by TOFMS and MS/MS. The tolerance range for the peak annotation was configured at \pm 0.5 min for MT and $\pm 10 \mathrm{ppm}$ for $\mathrm{m} / \mathrm{z}$. In addition, concentrations of metabolites were calculated by normalizing the peak area of each metabolite with respect to the area of the internal standard and by using standard curves, which were obtained by three-point calibrations.

\section{Oxygen consumption assay}

To examine glucose consumption in USC cancer cells, we used an oxygen consumption assay kit (MitoXpress Xtra ${ }^{\circledR}$ Oxygen Consumption Assay; \#2614060-3) purchased from Lucxel Biosciences Ltd. (Lucxel Biosciences Ltd., Cork, Ireland). The cells were seeded in a 96-well plate at a density of $8.0 \times 10^{4}$ cells in each well in $200 \mu \mathrm{L}$ of culture medium. The cells were incubated for 3 $\mathrm{h}$, and were adhered to the plate; culture medium was then removed and $90 \mu \mathrm{L}$ of fresh, warmed culture medium and $10 \mu \mathrm{L}$ of MitoXpress Xtra ${ }^{\circledR}$ reagent were added. Each well was sealed using mineral oil. Immediately, the plate was read using a fluorescence plate reader (Thermo Scientific VarioSkan ${ }^{\circledR}$ Flash, Thermo Fisher Scientific, Waltham, USA.). The excitation and emission spectra were $380 \mathrm{~nm}$ and $650 \mathrm{~nm}$, respectively.

\section{Immunoblot analysis}

Immunoblot analysis was performed as described previously [27]. Cells were washed with ice-cold phosphate-buffered saline (PBS) and lysed in radioimmunoprecipitation assay buffer [10 $\mathrm{mM}$ Tris$\mathrm{HCl}(\mathrm{pH} 7.4), 0.1 \%$ sodium dodecyl sulfate (SDS), $1 \%$ sodium deoxycholate, $150 \mathrm{mM} \mathrm{NaCl}, 1 \mathrm{mM}$ ethylenediaminetetraacetic acid, $1.5 \mathrm{mM} \mathrm{Na} \mathrm{VO}_{4}, 10$ $\mathrm{mM} \mathrm{NaF}, 10 \mathrm{mM}$ sodium pyrophosphate, $10 \mathrm{mM}$ sodium $\beta$-glycerophosphate and $1 \%$ protease inhibitor cocktail set III (Calbiochem)]. After centrifugation for $10 \mathrm{~min}$ at $14,000 \times g$ at $4^{\circ} \mathrm{C}$, the supernatants were recovered as the cell lysates; the protein concentrations of these cell lysates were determined using the bicinchoninic acid protein assay kit (Pierce Biotechnology, Inc., Rockford, IL, USA). Cell lysates containing equal amounts of protein were separated using SDS-polyacrylamide gel electrophoresis and transferred to a polyvinylidene difluoride membrane. The membrane was probed with a primary antibody and then with an appropriate horseradish peroxidase (HRP)conjugated secondary antibody according to the protocol recommended by the manufacturer of each antibody. Immunoreactive bands were visualized using Amersham ${ }^{\mathrm{TM}}$ ECL $^{\text {TM }}$ Prime Western Blotting Detection Reagent (GE Healthcare UK Ltd., Buckinghamshire, England).

\section{Flowcytometric analysis}

Dissociated cells were washed with ice-cold PBS, and fixed with ethanol at a final concentration of $70 \%$ ethanol. After storage overnight at $-25^{\circ} \mathrm{C}$, the cells were washed with PBS twice at room temperature. The cells were treated with ribonuclease $(30 \mathrm{mg} / \mathrm{mL})$ for $30 \mathrm{~min}$, and then treated with propidium iodide. All flow cytometric experiments were run using the FACSCanto ${ }^{\mathrm{TM}}$ II Flow Cytometer (BD Biosciences, Franklin Lakes, NJ, USA) and the data were analyzed using FlowJo software, version 7.6.5 (Treestar Inc., Ashland, OR, USA).

\section{Statistical analysis}

Results are expressed as the means \pm standard deviations (SD), and differences were compared using the two-tailed Student's $t$-test. $P<0.05$ was considered to indicate a statistically significant difference and is denoted using asterisks in the figures.

\section{CONFLICTS OF INTEREST}

The Authors declare no conflicts of interest.

\section{REFERENCES}

1. Morice P, Leary A, Creutzberg C, Abu-Rustum N, Darai E. Endometrial cancer. The Lancet. 2016; 387:1094-108. https://doi.org/10.1016/s0140-6736(15)00130-0.

2. Tropé C, Kristensen GB, Abeler VM. Clear-cell and papillary serous cancer: treatment options. Best Pract Res Clin Obstet Gynaecol. 2001; 15:433-46.

3. Matthews RP, Hutchinson-Colas J, Maiman M, Fruchter RG, Gates EJ, Gibbon D, Remy JC, Sedlis A. Papillary serous and clear cell type lead to poor prognosis of endometrial carcinoma in black women. Gynecol Oncol. 1997; 65:206-12.

4. Slomovitz BM, Burke TW, Eifel PJ, Ramondetta LM, Silva EG, Jhingran A, Oh JC, Atkinson EN, Broaddus RR, Gershenson DM, Lu KH. Uterine papillary serous carcinoma (UPSC): a single institution review of 129 cases. Gynecol Oncol. 2003; 91:463-69.

5. Podratz KC, Mariani A. Uterine papillary serous carcinomas: the exigency for clinical trials. Gynecol Oncol. 2003; 91:461-62.

6. Crum CP. Intercepting pelvic cancer in the distal fallopian tube: theories and realities. Mol Oncol. 2009; 3:165-70. https://doi.org/10.1016/j.molonc.2009.01.004.

7. Hendrickson M, Ross J, Eifel P, Martinez A, Kempson R. Uterine papillary serous carcinoma: a highly malignant form of endometrial adenocarcinoma. Am J Surg Pathol. 1982; 6:93-108.

8. Naumann RW. Uterine papillary serous carcinoma: state of the state. Curr Oncol Rep. 2008; 10:505-11.

9. Bristow RE, Asrari F, Trimble EL, Montz FJ. Extended surgical staging for uterine papillary serous carcinoma: survival outcome of locoregional (Stage I-III) disease. Gynecol Oncol. 2001; 81:279-86. 
10. Fader AN, Drake RD, O'Malley DM, Gibbons HE, Huh WK, Havrilesky LJ, Gehrig PA, Tuller E, Axtell AE, Zanotti KM, and Uterine Papillary Serous Carcinoma (UPSC) Consortium. Platinum/taxane-based chemotherapy with or without radiation therapy favorably impacts survival outcomes in stage I uterine papillary serous carcinoma. Cancer. 2009; 115:2119-27. https://doi.org/10.1002/ cncr.24247.

11. Kelly MG, O’Malley DM, Hui P, McAlpine J, Yu H, Rutherford TJ, Azodi M, Schwartz PE. Improved survival in surgical stage I patients with uterine papillary serous carcinoma (UPSC) treated with adjuvant platinum-based chemotherapy. Gynecol Oncol. 2005; 98:353-9. https://doi. org/10.1016/j.ygyno.2005.06.012.

12. Viswanathan AN, Macklin EA, Berkowitz R, Matulonis U. The importance of chemotherapy and radiation in uterine papillary serous carcinoma. Gynecol Oncol. 2011; 123:5427. https://doi.org/10.1016/j.ygyno.2011.09.005.

13. Roque DM, Bellone S, English DP, Buza N, Cocco E, Gasparrini S, Bortolomai I, Ratner E, Silasi DA, Azodi M, Rutherford TJ, Schwartz PE, Santin AD. Tubulin-beta-III overexpression by uterine serous carcinomas is a marker for poor overall survival after platinum/taxane chemotherapy and sensitivity to epothilones. Cancer. 2013; 119:2582-92. https://doi.org/10.1002/cncr.28017.

14. Munoz-Pinedo C, El Mjiyad N, Ricci JE. Cancer metabolism: current perspectives and future directions. Cell Death Dis. 2012; 3:e248. https://doi.org/10.1038/ cddis.2011.123.

15. Zhao Y, Butler EB, Tan M. Targeting cellular metabolism to improve cancer therapeutics. Cell Death Dis. 2013; 4:e532. https://doi.org/10.1038/cddis.2013.60.

16. Poisson LM, Munkarah A, Madi H, Datta I, Hensley-Alford S, Tebbe C, Buekers T, Giri S, Rattan R. A metabolomic approach to identifying platinum resistance in ovarian cancer. J Ovarian Res. 2015; 8:13. https://doi.org/10.1186/ s13048-015-0140-8.

17. Hsu IR, Kim SP, Kabir M, Bergman RN. Metabolic syndrome, hyperinsulinemia, and cancer. Am J Clin Nutr. 2007; 86:s867-71.

18. Kuhajda FP. Fatty-acid synthase and human cancer: new perspectives on its role in tumor biology. Nutrition. 2000; 16:202-08.

19. Zhou W, Tu Y, Simpson PJ, Kuhajda FP. Malonyl-CoA decarboxylase inhibition is selectively cytotoxic to human breast cancer cells. Oncogene. 2009; 28:2979-87.

20. Patra S, Bera S, SinhaRoy S, Ghoshal S, Ray S, Basu A, Schlattner U, Wallimann T, Ray M. Progressive decrease of phosphocreatine, creatine and creatine kinase in skeletal muscle upon transformation to sarcoma. FEBS J. 2008; 275:3236-47. https://doi. org/10.1111/j.1742-4658.2008.06475.x.

21. Yan YB. Creatine kinase in cell cycle regulation and cancer. Amino Acids. 2016; 48:1775-84. https://doi.org/10.1007/ s00726-016-2217-0.
22. Bera S, Wallimann T, Ray S, Ray M. Enzymes of creatine biosynthesis, arginine and methionine metabolism in normal and malignant cells. FEBS J. 2008; 275:5899-909. https:// doi.org/10.1111/j.1742-4658.2008.06718.x.

23. Jeon H, Kim JH, Lee E, Jang YJ, Son JE, Kwon JY, Lim TG, Kim S, Park JH, Kim JE, Lee KW. Methionine deprivation suppresses triple-negative breast cancer metastasis in vitro and in vivo. Oncotarget. 2016; 7:67223-34. https://doi. org/10.18632/oncotarget.11615.

24. Chakraborty PK, Xiong X, Mustafi SB, Saha S, Dhanasekaran D, Mandal NA, McMeekin S, Bhattachar ya R, Mukherjee P. Role of cystathionine beta synthase in lipid metabolism in ovarian cancer. Oncotarget. 2015; 6:3736784. https://doi.org/10.18632/oncotarget.5424.

25. Shatalin K, Shatalina E, Mironov A, Nudler E. H2S: a universal defense against antibiotics in bacteria. Science. 2011; 334:986-90. https://doi.org/10.1126/science.1209855.

26. Garber K. Energy boost: the Warburg effect returns in a new theory of cancer. J Natl Cancer Inst. 2004; 96:1805-06. https://doi.org/10.1093/jnci/96.24.1805.

27. Shibuya K, Okada M, Suzuki S, Seino M, Seino S, Takeda $\mathrm{H}$, Kitanaka C. Targeting the facilitative glucose transporter GLUT1 inhibits the self-renewal and tumor-initiating capacity of cancer stem cells. Oncotarget. 2015; 6:651-61. https://doi.org/10.18632/oncotarget.2892.

28. Warburg O. On the origin of cancer cells. Science. 1956; 123:309-14.

29. Caro P, Kishan AU, Norberg E, Stanley IA, Chapuy B, Ficarro SB, Polak K, Tondera D, Gounarides J, Yin H, Zhou F, Green MR, Chen L, et al. Metabolic signatures uncover distinct targets in molecular subsets of diffuse large B cell lymphoma. Cancer Cell. 2012; 22:547-60. https://doi. org/10.1016/j.ccr.2012.08.014.

30. Marin-Valencia I, Yang C, Mashimo T, Cho S, Baek H, Yang XL, Rajagopalan KN, Maddie M, Vemireddy V, Zhao Z, Cai L, Good L, Tu BP, et al. Analysis of tumor metabolism reveals mitochondrial glucose oxidation in genetically diverse human glioblastomas in the mouse brain in vivo. Cell Metab. 2012; 15:827-837. https://doi. org/10.1016/j.cmet.2012.05.001.

31. Dar S, Chhina J, Mert I, Chitale D, Buekers T, Kaur H, Giri S, Munkarah A, Rattan R. Bioenergetic Adaptations in Chemoresistant Ovarian Cancer Cells. Sci Rep. 2017; 7:8760. https://doi.org/10.1038/s41598-017-09206-0.

32. Vander Heiden MG, DeBerardinis RJ. Understanding the intersections between metabolism and cancer biology. Cell. 2017; 168:657-669. https://doi.org/10.1016/j. cell.2016.12.039.

33. Chen RS, Song YM, Zhou ZY, Tong T, Li Y, Fu M, Guo XL, Dong LJ, He X, Qiao HX, Zhan QM, Li W. Disruption of $\mathrm{xCT}$ inhibits cancer cell metastasis via the caveolin-1/betacatenin pathway. Oncogene. 2009; 28:599-609. https://doi. org/10.1038/onc.2008.414.

34. Ishimoto $\mathrm{T}$, Nagano $\mathrm{O}$, Yae $\mathrm{T}$, Tamada M, Motohara $\mathrm{T}$, Oshima H, Oshima M, Ikeda T, Asaba R, Yagi H, Masuko T, 
Shimizu $\mathrm{T}$, Ishikawa $\mathrm{T}$, et al. CD44 variant regulates redox status in cancer cells by stabilizing the $\mathrm{xCT}$ subunit of system $\mathrm{xc}(-)$ and thereby promotes tumor growth. Cancer Cell. 2011; 19:387-400. https://doi.org/10.1016/j. ccr.2011.01.038.

35. Wang Q, Zheng XL, Yang L, Shi F, Gao LB, Zhong YJ, Sun H, He F, Lin Y, Wang X. Reactive oxygen speciesmediated apoptosis contributes to chemosensitization effect of saikosaponins on cisplatin-induced cytotoxicity in cancer cells. J Exp Clin Cancer Res. 2010; 29:159. https://doi. org/10.1186/1756-9966-29-159.

36. Santin AD, Bellone S, Gokden M, Palmieri M, Dunn D, Agha J, Roman JJ, Hutchins L, Pecorelli S, O'Brien T, Cannon MJ, Parham GP. Overexpression of HER-2/neu in uterine serous papillary cancer. Clin Cancer Res. 2002; 8:1271-79.

37. Seino M, Okada M, Sakaki H, Takeda H, Watarai H, Suzuki S, Seino S, Kuramoto K, Ohta T, Nagase S, Kurachi H, Kitanaka C. Time-staggered inhibition of JNK effectively sensitizes chemoresistant ovarian cancer cells to cisplatin and paclitaxel. Oncol Rep. 2016; 35:593-601. https://doi. org/10.3892/or.2015.4377.

38. Suzuki S, Okada M, Shibuya K, Seino M, Sato A, Takeda H, Seino S, Yoshioka T, Kitanaka C. JNK suppression of chemotherapeutic agents-induced ROS confers chemoresistance on pancreatic cancer stem cells. Oncotarget. 2015; 6:458-70. https://doi.org/10.18632/oncotarget.2693.

39. Kiguchi K, Kubota T, Aoki D, Udagawa Y, Yamanouchi S, Saga M, Amemiya A, Sun FX, Nozawa S, Moossa AR, Hoffman RM. A patient-like orthotopic implantation nude mouse model of highly metastatic human ovarian cancer. Clin Exp Metastasis. 1998; 16:751-56.

40. Makinoshima H, Takita M, Matsumoto S, Yagishita A, Owada S, Esumi H, Tsuchihara K. Epidermal growth factor receptor (EGFR) signaling regulates global metabolic pathways in EGFR-mutated lung adenocarcinoma. J Biol Chem. 2014; 289:20813-23. https://doi.org/10.1074/jbc. M114.575464.

41. Sugimoto M, Wong DT, Hirayama A, Soga T, Tomita M. Capillary electrophoresis mass spectrometry-based saliva metabolomics identified oral, breast and pancreatic cancerspecific profiles. Metabolomics. 2010; 6:78-95. https://doi. org/10.1007/s11306-009-0178-y. 